\title{
Association of the interleukin-22 genetic polymorphisms with ulcerative colitis
}

\author{
Hong Gang Chi ${ }^{1 \dagger}$, Xue Bao Zheng ${ }^{1 \dagger}$, Zhu Guo Wu ${ }^{2}$, Shi Xue Dai ${ }^{3}$, Zheng Wan ${ }^{4}$ and Ying Zou ${ }^{1,4^{*}}$
}

\begin{abstract}
Background: Interleukin-22 (IL-22) is a member of the IL-10 family of anti-inflammatory cytokines that mediates epithelial immunity. IL-22 expression was found to be increased in patients with ulcerative colitis (UC). Whether genetic polymorphisms of $I L-22$ also influence $U C$ risk is still unknown. The purpose of this study was to investigate the association between the $/ L-22$ gene polymorphisms ( $-429 \mathrm{C} / \mathrm{T},+1046 \mathrm{~T} / \mathrm{A}$ and $+1995 \mathrm{~A} / \mathrm{C})$ and the risk of UC in Chinese Han patients.

Methods: This hospital-based case-control study comprised 180 patients with UC and 180 age- and gender-matched controls. Genotypes of 3 common polymorphisms of the $\mathrm{L}-22$ gene were determined by fluorogenic 5 ' exonuclease assays (TaqMan).

Results: Patients with UC had a significantly higher frequency of IL-22 -429 TT genotype [odds ratio (OR) $=2.43$, 95\% confidence interval $(\mathrm{Cl})=1.35,4.37 ; P=0.003]$ and $-429 \mathrm{~T}$ allele $(\mathrm{OR}=1.54,95 \% \mathrm{Cl}=1.14,2.07 ; P=0.004)$ than controls. The findings are still emphatic by the Bonferroni correction. The IL-22+1046 T/A and IL-22+1995 A/C gene polymorphisms were not associated with a risk of UC. When stratifying by clinical type, location and disease severity of UC, no significant differences were found in any groups.
\end{abstract}

Conclusion: This is the first study to provide evidence for an association of $I L-22-429 \mathrm{C} / \mathrm{T}$ gene polymorphisms with UC risk. Additional well-designed large studies were required for the validation of our results.

Virtual Slides: The virtual slide(s) for this article can be found here: http://www.diagnosticpathology.diagnomx.eu/vs/ 13000_2014_183

Keywords: Interleukin-22, Gene polymorphism, Ulcerative colitis, Case-control study

\section{Background}

Ulcerative colitis (UC), as the most common form of inflammatory bowel disease (IBD), is a form of colitis that includes characteristic ulcers, or open sores [1]. Ulcerative colitis has an incidence of 1 to 20 cases per 100,000 individuals per year, and a prevalence of 8 to 246 per 100,000 individuals [2]. Patients with UC have an increased risk of developing colorectal cancer [3]. The pathogenesis of UC is not well defined, but it is proposed that genetic and environmental factors result in

\footnotetext{
*Correspondence: yzou98@hotmail.com

${ }^{\dagger}$ Equal contributors

'Department of Traditional Chinese Medicine, The Second Clinical Medical College, Guangdong Medical College, 1 Xincheng Road, Songshan LakeSci. \&Tech, Industry Park, Dongguan, Guangdong 523808, China

${ }^{4}$ Sino-American Cancer Research Institute, Guangdong Medical College, Dongguan 523808, China

Full list of author information is available at the end of the article
}

an aberrant immune response to a subset of commensal enteric bacteria $[4,5]$. Recent genome-wide association (GWA) studies and meta-analyses have identified many single-nucleotide polymorphisms (SNPs) associated with $\mathrm{UC}[6,7]$.

Interleukin-22 (IL-22) is a member of the $I L-10$ family of anti-inflammatory cytokines that mediates epithelial immunity [8]. IL-22 is synthesized by different cell types including T- and NK-cells, and has been reported to mediate the crosstalk between inflammatory cells and keratinocytes [9-11]. IL-22 expression was induced in several human inflammatory conditions, including IBD $[12,13]$. IL-22 expression was found to be increased in patients with UC [14]. Several SNPs have previously been identified in the $I L-22$ gene [15-22].

Whether genetic polymorphisms of IL-22 also influence UC risk is still unknown. The aim of this study was 
to investigate the association between the $I L-22$ gene polymorphisms $(-429 \mathrm{C} / \mathrm{T},+1046 \mathrm{~T} / \mathrm{A}$ and $+1995 \mathrm{~A} / \mathrm{C})$ and the risk of UC in Chinese Han patients.

\section{Methods}

\section{Study subjects}

This hospital-based case-control study comprised 180 patients with UC and 180 age- and gender-matched controls during the years 2009 to 2014. Diagnosis of UC was based on clinical, radiological, endoscopic and histological examinations [23]. To confirm the diagnosis, two physicians reviewed the hospital records and validated each case. The location of disease was defined according to the Montreal classification (ulcerative proctitis, leftsided colitis, and extensive colitis) [24]. The severity of UC was determined according to Truelove and Witts criteria (mild colitis, moderate colitis, and severe colitis) [25]. According to their clinical courses, UC cases were classified into one episode, relapsing and continuous phenotypes [26]. The control group was composed of age- and gender-matched subjects who had undergone an endoscopic examinations in the same recruitment period as the UC patients, without evidence of UC. In addition, similar to the cases the controls were all required to be born in China to native Chinese Han parents. Informed consent was obtained from all subjects after a full explanation of the project according to the Declaration of Helsinki, and the specimen collecting procedures were approved by the Institutional Ethical Committee of Guangdong Medical College.

\section{Genotyping}

Whole blood (3-6 ml) was obtained by venepuncture using standard EDTA collection tubes. DNA was extracted using the QIAGEN Gentra Puregene blood kit (QIAGEN Inc., Valencia, CA, USA). Genotypes of 3 common polymorphisms of the $I L-22$ gene were determined by fluorogenic $5^{\prime}$ exonuclease assays (TaqMan). Primer and probe sequences for $5^{\prime}$-exonuclease assays for $I L-22$ polymorphisms were listed in Table 1 . The polymerase chain reaction (PCR) was performed in a Primus 96 plus thermal cycler using a total volume of $5 \mu \mathrm{l}$ containing $2.5 \mu \mathrm{l}$ of Universal-MasterMix, $0.125 \mu \mathrm{l}$ 40x Assay-by- Design mix, $0.375 \mu \mathrm{l} \mathrm{H}_{2} \mathrm{O}$ and $2 \mu \mathrm{l}$ DNA. Reactions were overlaid with $15 \mu \mathrm{l}$ of mineral oil. Cycling parameters were: $10 \mathrm{~min}$ at $94^{\circ} \mathrm{C}$ for primary denaturation, followed by 40 cycles of $20 \mathrm{~s}$ at $92^{\circ} \mathrm{C}$ and $1 \mathrm{~min}$ at $60^{\circ} \mathrm{C}$. Fluorescence was measured in a lambda Fluoro 320 Plus plate reader (MWG Biotech AG, Germany).

\section{Statistical analysis}

STATA program version 11.0 (StataCorp LP, TX) was used for statistical analyses. Continuous variables were analysed by $t$-test and presented as mean \pm standard deviation (SD). Categorical variables are presented as percentages and were compared by chi-squared test. Odds ratio (OR) and 95\% confidence intervals (CI) were determined by logistic regression analysis. For a new work, we also use the Bonferroni correction for total number of independent comparisons. The Hardy-Weinberg equilibrium was tested for goodness-of-fit chi-square test with one degree of freedom to compare the observed genotype frequencies among the subjects with the expected genotype frequencies. The $P$-value less than 0.05 was considered statistically significant.

\section{Results}

\section{Characteristics of participants}

Demographic and clinical characteristics of study participants were showed in Table 2. No significant differences were found between the UC cases and controls in age, sex, body mass index (BMI), smoking status and family history of inflammatory bowel disease (IBD) (Table 2). The genotype were in agreement with the Hardy-Weinberg equilibrium.

\section{IL-22 -429C/T polymorphisms and UC}

Patients with UC had a significantly higher frequency of $I L-22-429$ TT genotype $(\mathrm{OR}=2.43,95 \% \mathrm{CI}=1.35,4.37$; $P=0.003)$ and $-429 \mathrm{~T}$ allele $(\mathrm{OR}=1.54,95 \% \mathrm{CI}=1.14$, 2.07; $P=0.004$ ) than controls (Table 3 ). The findings are still emphatic by the Bonferroni correction. When stratifying by clinical type, location and disease severity of $\mathrm{UC}$, no significant differences were found in any groups (Table 4).

Table 1 Primer and probe sequences for 5'-exonuclease assays for IL-22 polymorphisms

\begin{tabular}{cccc}
\hline \multicolumn{1}{c}{ SNPs } & rs2227485 & rs1182844 & rs1179246 \\
\hline Exchange & $-429 \mathrm{C} / T$ & +1046 T/A & +1995 A/C \\
Forward Primer & AAAATGAGTCCGTGACCAAAATGC & CCACCTATGAGACTTCCCTATCAGT & GAAAAAGCCTTCCTGCCTAATGG \\
Reverse Primer & ACACAATTGTTTGTCTTAGTAGAGTTCAGAT & CACTAAAGGAAAAGGAAAGCTGTGTT & GGTGCTGCCTAAAGGTCAGA \\
Wildtype-Probe & FAM-CTCCTATAGTGACTGAGTAA-NFQ & VIC-AAACTTACTAGTAGGTATGACTC-NFQ & VIC-TGAACAGAGTTATCTGCCTC-NFQ \\
Mutant-Probe & VIC-CTCCTATAGTGGCTGAGTAA-NFQ & FAM-CTTACTAGTAGGAATGACTC-NFQ & FAM-AACAGAGTTAGCTGCCTC-NFQ \\
\hline
\end{tabular}


Table 2 Demographic and clinical characteristics of study participants

\begin{tabular}{lccc}
\hline & UC & Controls & $\boldsymbol{P}$ \\
\hline Number of subjects & 180 & 180 & \\
Sex (Male/Female) & $95 / 85$ & $98 / 82$ & 0.75 \\
Age (years, mean \pm SD) & $39.7 \pm 12.5$ & $40.2 \pm 13.1$ & 0.71 \\
BMI (kg/m ${ }^{2}$, mean \pm SD) & $20.2 \pm 3.7$ & $19.8 \pm 3.5$ & 0.29 \\
Smoking status (Ever/Never) & $79 / 101$ & $75 / 105$ & 0.67 \\
Family history of IBD (Positive/Negative) & $14 / 166$ & $11 / 169$ & 0.54 \\
\hline Clinical type & & & \\
$\quad$ One episode & 16 & & \\
$\quad$ Relapsing & 70 & & \\
Continuous & 94 & & \\
\hline Location & & & \\
Proctitis (E1) & 73 & & \\
Left side (E2) & 64 & & \\
Extensive (E3) & 43 & & \\
\hline Disease severity & & & \\
Mild & 76 & \\
Moderate & 95 & \\
Severe & 9 & \\
\hline
\end{tabular}

Abbreviations: UC ulcerative colitis, $B M I$ body mass index, IBD inflammatory bowel disease.

\section{IL-22 +1046 T/A polymorphisms and UC}

The $I L-22+1046$ T/A gene polymorphisms were not associated with a risk of UC (Table 3). When stratifying by clinical type, location and disease severity of UC, no significant differences were found in any groups (Table 5).

\section{IL-22 +1995 A/C polymorphisms and UC}

The $I L-22+1995 \mathrm{~A} / \mathrm{C}$ gene polymorphisms were not associated with a risk of UC (Table 3 ). When stratifying by clinical type, location and disease severity of UC, no significant differences were found in any groups (Table 6).

\section{Discussion}

Recently, many studies have identified many SNPs associated with UC. A case-control study in 139 and 176 patients with UC and controls found that polymorphisms in CD14-159 C/T and TLR4-299 A/G significantly affected mCD14 and mTLR4 expression levels and also increased susceptibility to UC [27]. A case-control study in a Korean population suggested that the $-1920 \mathrm{G}>\mathrm{A}$ polymorphism in IFITM1 may be associated with susceptibility to UC $(P=0.002)$ [28]. A case-control study in a group of 198 Mexican Mestizo patients with UC and 698 ethnically matched healthy unrelated individuals with no family history of UC suggested that the GG genotypes of the $I L-20$ polymorphisms (rs2981573 and rs2232360) might have an important role in the development of UC $(P=0.017)$ in the Mexican population [29]. A case-control study in 56 patients with UC and 50 healthy controls suggested that the $I L-10-819 \mathrm{CC}$ was a candidate genotype for both IBS $(P=0.047)$ and UC $(P=$ $0.007)$ in Japanese [30]. A case-control study suggested that the $-1850 \mathrm{G} / \mathrm{C}$ polymorphism in the embryonic ectoderm development (EED) gene might be associated with the susceptibility to UC $(P=0.018)$ by the change of the EED expression level [31]. A meta-analysis of seventeen studies with 18,308 cases and 20,406 controls indicated that the PTPN2 polymorphism (rs2542151) was associated

Table 3 Genotype and allele frequencies of IL-22 gene polymorphisms among ulcerative colitis cases and healthy controls

\begin{tabular}{|c|c|c|c|c|}
\hline Genotypes & $U C(n=150)$ & Controls $(n=150)$ & OR $(95 \% \mathrm{Cl})$ & $P$ \\
\hline-429 CC & $57(31.7)$ & $68(37.8)$ & 1.00(Reference) & \\
\hline$-429 \mathrm{CT}$ & $70(38.9)$ & $86(47.8)$ & $0.97(0.61,1.56)$ & 0.90 \\
\hline$-429 \pi$ & $53(29.4)$ & $26(14.4)$ & $2.43(1.35,4.37)$ & 0.003 \\
\hline$-429 \mathrm{C}$ allele frequency & 184(51.1) & $222(61.7)$ & 1.00(Reference) & \\
\hline -429 T allele frequency & 176(48.9) & 138(38.3) & $1.54(1.14,2.07)$ & 0.004 \\
\hline +1046 TT & $88(48.9)$ & $94(52.2)$ & 1.00(Reference) & \\
\hline +1046 TA & $63(35.0)$ & $61(33.9)$ & $1.10(0.70,1.74)$ & 0.67 \\
\hline$+1046 \mathrm{AA}$ & $29(16.1)$ & 25(13.9) & $1.24(0.67,2.28)$ & 0.49 \\
\hline +1046 T allele frequency & $239(66.4)$ & $249(69.2)$ & 1.00(Reference) & \\
\hline +1046 A allele frequency & $121(33.6)$ & $111(30.8)$ & $1.14(0.83,1.55)$ & 0.43 \\
\hline +1995 AA & $76(42.2)$ & $81(45.0)$ & 1.00(Reference) & \\
\hline +1995 AC & $65(36.1)$ & 63(35.0) & $1.10(0.69,1.75)$ & 0.69 \\
\hline +1995 CC & $39(21.7)$ & $36(20.0)$ & $1.16(0.67,2.00)$ & 0.61 \\
\hline +1995 A allele frequency & $217(60.3)$ & $225(62.5)$ & 1.00(Reference) & \\
\hline +1995 C allele frequency & 143(39.7) & 135(37.5) & $1.10(0.81,1.48)$ & 0.54 \\
\hline
\end{tabular}

Abbreviations: UC ulcerative colitis, OR odds ratio, $\mathrm{Cl}$ confidence interval. 
Table 4 Stratification analysis of IL-22-429 C/T polymorphisms in ulcerative colitis cases

\begin{tabular}{|c|c|c|c|c|c|c|c|c|c|c|}
\hline & \multirow{2}{*}{$\begin{array}{c}\text { Cases } \\
(n=180)\end{array}$} & \multicolumn{3}{|c|}{ CC } & \multicolumn{3}{|c|}{ CT } & \multicolumn{3}{|c|}{$\mathrm{TT}$} \\
\hline & & n (\%) & OR (95\% Cl) & $P$ & n (\%) & OR $(95 \% \mathrm{Cl})$ & $P$ & n (\%) & OR $(95 \% \mathrm{Cl})$ & $P$ \\
\hline Clinical type & 180 & $57(31.7)$ & 1(Reference) & & $70(38.9)$ & 1(Reference) & & $53(29.4)$ & 1(Reference) & \\
\hline One episode & 16 & $5(31.2)$ & $0.99(0.35,2.81)$ & 0.98 & $7(43.8)$ & $1.13(0.44,2.85)$ & 0.80 & $4(25.0)$ & $0.85(0.27,2.65)$ & 0.78 \\
\hline Relapsing & 70 & 24(34.3) & $1.08(0.62,1.88)$ & 0.78 & $26(37.1)$ & $0.96(0.56,1.62)$ & 0.87 & 20(28.6) & $0.97(0.54,1.74)$ & 0.92 \\
\hline Continuous & 94 & 28(29.8) & $0.94(0.56,1.58)$ & 0.82 & $37(39.4)$ & $1.01(0.63,1.62)$ & 0.96 & 29(30.8) & $1.05(0.63,1.76)$ & 0.86 \\
\hline Location & 180 & 57(31.7) & 1(Reference) & & $70(38.9)$ & 1 (Reference) & & $53(29.4)$ & 1(Reference) & \\
\hline Proctitis (E1) & 73 & 24(32.9) & $1.04(0.60,1.80)$ & 0.89 & $27(37.0)$ & $0.95(0.57,1.60)$ & 0.85 & $22(30.1)$ & $1.02(0.58,1.80)$ & 0.94 \\
\hline Left side (E2) & 64 & 20(31.3) & $0.99(0.55,1.77)$ & 0.97 & $26(40.6)$ & $1.05(0.61,1.78)$ & 0.87 & 18(28.1) & $0.96(0.52,1.75)$ & 0.88 \\
\hline Extensive (E3) & 43 & 13(30.2) & $0.96(0.48,1.90)$ & 0.89 & 17(39.6) & $1.02(0.54,1.90)$ & 0.96 & 13(30.2) & $1.03(0.51,2.05)$ & 0.94 \\
\hline Disease severity & 180 & $57(31.7)$ & 1(Reference) & & $70(38.9)$ & 1(Reference) & & $53(29.4)$ & 1(Reference) & \\
\hline Mild & 76 & 25(32.9) & $1.04(0.61,1.79)$ & 0.89 & $28(36.8)$ & $0.95(0.57,1.58)$ & 0.84 & $23(30.3)$ & $1.03(0.59,1.80)$ & 0.92 \\
\hline Moderate & 95 & 29(30.5) & $0.96(0.58,1.61)$ & 0.89 & $38(40.0)$ & $1.03(0.65,1.64)$ & 0.91 & 28(29.5) & $1.00(0.59,1.68)$ & 0.99 \\
\hline Severe & 9 & $3(33.3)$ & $1.05(0.28,4.02)$ & 0.94 & $4(44.5)$ & $1.14(0.34,3.83)$ & 0.83 & $2(22.2)$ & $0.76(0.16,3.60)$ & 0.72 \\
\hline
\end{tabular}

with increased UC risk [32]. A meta-analysis of nine studies indicated that the vitamin $\mathrm{D}$ receptor $(V D R)$ polymorphisms were associated with increased UC risk [33]. A meta-analysis suggested that the migration inhibitory factor $(M I F)$ gene $-173 \mathrm{G} / \mathrm{C}$ polymorphism contributed to the susceptibility of UC [34]. A case-control study included 422 very-early-onset IBD subjects and 480 healthy subjects suggested that $I L-10 R$ polymorphisms were associated with very-early-onset ulcerative colitis $(P=0.0002)$ [35]. A case-control study included $171 \mathrm{UC}$ and 213 healthy controls found that polymorphisms in XRCC1 Arg399Gln and APE1 Asp148Glu significantly increased the rate of apoptosis and risk of UC $(P=0.0007)$ [36]. A case-control study in a group of 200 Mexican patients with UC and 248 ethnically matched unrelated healthy controls suggested that $I L-1 R N$ and $I L-1 B$ polymorphisms were associated with the genetic susceptibility to develop $\mathrm{UC}$ and might be associated with the presence of steroid-dependence in UC patients $(P=0.019)$ [37]. A case-control study in a group of 200 Mexican Mestizo patients with UC and 698 healthy unrelated individuals with no family history of UC suggested that IL-19 polymorphisms (rs2243188 and rs2243193) might have a protective role in the development of UC $(P=0.018$ and $P=0.006$, respectively) in Mexican individuals [38].

IL-22 expression was involved in several human inflammatory conditions and autoimmune diseases. A study included $631 \mathrm{HCV}$ patients found that $I L-22$ polymorphisms were involved in the progression of persistent hepatitis $\mathrm{C}$ virus infection [15]. A case-control study in 206 cases and 196 controls suggested that Polymorphisms in the $I L-22$ receptor alpha-1 gene were associated with severe chronic

Table 5 Stratification analysis of IL-22 + 1046 T/A polymorphisms in ulcerative colitis cases

\begin{tabular}{|c|c|c|c|c|c|c|c|c|c|c|}
\hline & \multirow{2}{*}{$\begin{array}{c}\text { Cases } \\
(n=180)\end{array}$} & \multicolumn{3}{|c|}{ TT } & \multicolumn{3}{|c|}{ TA } & \multicolumn{3}{|c|}{ AA } \\
\hline & & n (\%) & OR $(95 \% \mathrm{Cl})$ & $P$ & n (\%) & OR $(95 \% \mathrm{Cl})$ & $P$ & n (\%) & OR $(95 \% \mathrm{Cl})$ & $P$ \\
\hline Clinical type & 180 & $88(48.9)$ & 1(Reference) & & 63(35.0) & 1(Reference) & & $29(16.1)$ & 1(Reference) & \\
\hline One episode & 16 & $7(43.7)$ & $0.89(0.35,2.55)$ & 0.81 & 6(37.6) & $1.07(0.40,2.86)$ & 0.89 & $3(18.7)$ & $1.16(0.32,4.25)$ & 0.82 \\
\hline Relapsing & 70 & $33(47.1)$ & $0.96(0.59,1.57)$ & 0.88 & $26(37.2)$ & $1.06(0.62,1.81)$ & 0.83 & $11(15.7)$ & $0.98(0.46,2.06)$ & 0.95 \\
\hline Continuous & 94 & $48(51.1)$ & $1.04(0.68,1.61)$ & 0.84 & $31(33.0)$ & $0.94(0.57,1.55)$ & 0.82 & 15(15.9) & $0.99(0.51,1.94)$ & 0.98 \\
\hline Location & 180 & $88(48.9)$ & 1 (Reference) & & 63(35.0) & 1(Reference) & & $29(16.1)$ & 1(Reference) & \\
\hline Proctitis (E1) & 73 & $37(50.7)$ & $1.04(0.65,1.66)$ & 0.88 & $25(34.2)$ & $0.98(0.57,1.67)$ & 0.94 & $11(15.1)$ & $0.94(0.44,1.97)$ & 0.86 \\
\hline Left side (E2) & 64 & $33(51.6)$ & $1.06(0.65,1.72)$ & 0.83 & $21(32.8)$ & $0.94(0.53,1.66)$ & 0.82 & 10(15.6) & $0.97(0.45,2.10)$ & 0.94 \\
\hline Extensive (E3) & 43 & 18(41.9) & $0.86(0.47,1.57)$ & 0.62 & $17(39.5)$ & $1.13(0.60,2.12)$ & 0.70 & $8(18.6)$ & $1.16(0.49,2.70)$ & 0.74 \\
\hline Disease severity & 180 & $88(48.9)$ & 1 (Reference) & & 63(35.0) & 1(Reference) & & $29(16.1)$ & 1(Reference) & \\
\hline Mild & 76 & $35(46.1)$ & $0.94(0.59,1.51)$ & 0.81 & $28(36.8)$ & $1.05(0.63,1.77)$ & 0.85 & 13(17.1) & $1.06(0.52,2.15)$ & 0.87 \\
\hline Moderate & 95 & $48(50.5)$ & $1.03(0.67,1.59)$ & 0.88 & $32(33.7)$ & $0.96(0.59,1.58)$ & 0.88 & 15(15.8) & $0.98(0.50,1.92)$ & 0.95 \\
\hline Severe & 9 & $5(55.6)$ & $1.14(0.37,3.49)$ & 0.82 & $3(33.3)$ & $0.95(0.25,3.63)$ & 0.94 & $1(11.1)$ & $0.69(0.08,5.65)$ & 0.73 \\
\hline
\end{tabular}


Table 6 Stratification analysis of IL-22 +1995 A/C polymorphisms in ulcerative colitis cases

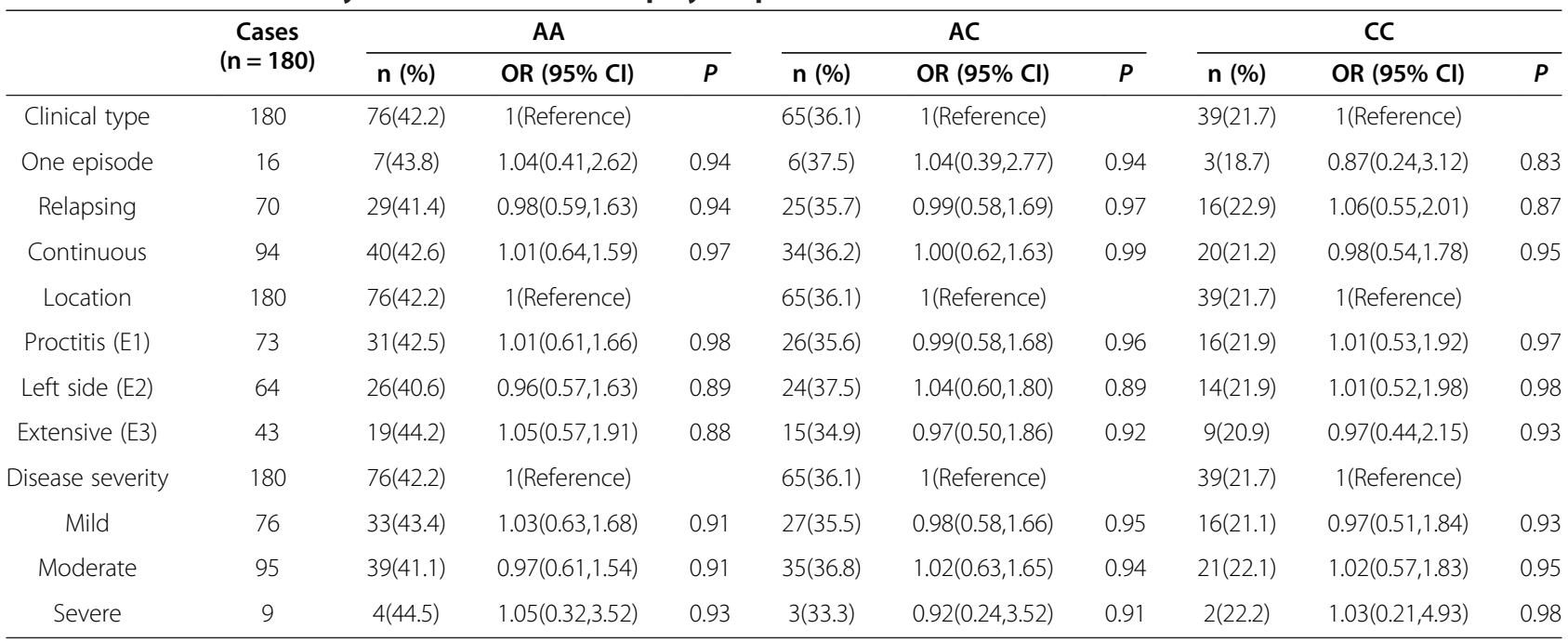

rhinosinusitis $(P=0.0014)$ [16]. A case-control study in 194 patients and 287 normal controls suggested that polymorphism of $I L-22$ receptor alpha-1 was associated with the development of childhood IgA nephropathy $(P=$ 0.002) [22]. IL-22 deficiency may contribute to the pathogenesis of certain chronic disorders as postulated in this paper for acne inversa [39]. A study included 94 patients with COPD, 23 healthy smokers, and 22 healthy control non-smokers found that the increased sputum $I L-22$ might also play important roles in the pathogenesis of chronic obstructive pulmonary disease $(P<0.01)$ [40]. A case-control study indicated that there was an increased expression level of $I L-22$ and $I L-23$ in patients with periimplantitis $(P<0.05)$ [41]. A study in 18 cases and 21 controls suggested that increased expression of $I L-22$ was associated with disease activity in Behcet's disease [42]. IL-22 has been reported to be involved in systemic sclerosis lesions [43]. A study included allergic asthma $(\mathrm{n}=18)$, controlled asthma $(\mathrm{n}=17)$ and healthy controls $(\mathrm{n}=12)$ found that $I L-22$ might be involved in the pathogenesis of allergic asthma in human and the level of $I L-22$ might have some relationship with the severity of the disease $(P<0.05)$ [44].

Our results should be taken with caution for some limitations. First of all, the numbers of subjects included in this study were small, and may not have been sufficient to reveal the associations between the $I L-22$ gene polymorphisms $(-429 \mathrm{C} / \mathrm{T},+1046 \mathrm{~T} / \mathrm{A}$ and $+1995 \mathrm{~A} / \mathrm{C})$ and the risk of UC. Secondly, our investigation was not based on genome wide screening, but UC was induced by multiple genes and environmental factors, which were not explored in the present study. Thirdly, the participants in our research are only from Han Chinese ethnic group. It would be interesting to conduct similar studies in different populations for comparison. Finally, this is a hospital based case control study, so the selection bias cannot be avoidable and the subjects may not be representative of the general population.

\section{Conclusions}

In conclusion, this study provides evidence for an association of $I L-22-429 \mathrm{C} / \mathrm{T}$ gene polymorphisms with UC risk. To the best of our knowledge this is the first study to provide evidence about the role of $I L-22$ polymorphisms in the development of UC. Additional welldesigned large-scale multicenter studies were required for the validation of our results.

\section{Competing interests}

The authors declare that they have no competing interests.

\section{Authors' contributions}

HGC and YZ carried out the molecular genetic studies and drafted the manuscript. XBZ carried out the genotyping. ZGW and SXD participated in the design of the study and performed the statistical analysis. HGC, XBZ, ZGW, SXD, ZW and YZ conceived of the study, and participated in its design and coordination and helped to draft the manuscript. All authors read and approved the final manuscript.

\section{Authors' information}

Hong Gang Chi and Xue Bao Zheng are joint first authors.

\section{Acknowledgment}

This investigation was funded by the National Natural Science Foundation of China (NSFC, No. 81173240), Science and Technology Planning Project of Guangdong Province (No. 2013B032500019), China and the PhD Start-up Fund of Guangdong Medical College (No. B2013005, B2013006).

\section{Author details}

'Department of Traditional Chinese Medicine, The Second Clinical Medical College, Guangdong Medical College, 1 Xincheng Road, Songshan LakeSci. \&Tech, Industry Park, Dongguan, Guangdong 523808, China. ${ }^{2}$ The Second Clinical Medical College, Guangdong Medical College, Dongguan 523808, China. ${ }^{3}$ Emergency Department of Nanfang Hospital, Southern Medical University, Guangzhou 510515, China. ${ }^{4}$ Sino-American Cancer Research Institute, Guangdong Medical College, Dongguan 523808, China. 
Received: 8 August 2014 Accepted: 7 September 2014 Published online: 09 October 2014

\section{References}

1. Tyler AD, Milgrom R, Stempak JM, Xu W, Brumell JH, Muise AM, Sehgal R, Cohen Z, Koltun W, Shen B, Silverberg MS: The NOD2insC polymorphism is associated with worse outcome following ileal pouch-anal anastomosis for ulcerative colitis. Gut 2013, 62:1433-1439.

2. Danese S, Fiocchi C: Ulcerative colitis. N Engl J Med 2011, 365:1713-1725.

3. Jess T, Rungoe C, Peyrin-Biroulet L: Risk of colorectal cancer in patients with ulcerative colitis: a meta-analysis of population-based cohort studies. Clin Gastroenterol Hepatol 2012, 10:639-645.

4. Sartor RB: Mechanisms of disease: pathogenesis of Crohn's disease and ulcerative colitis. Nat Clin Pract Gastroenterol Hepatol 2006, 3:390-407.

5. Jostins L, Ripke S, Weersma RK, Duerr RH, McGovern DP, Hui KY, Lee JC, Schumm LP, Sharma Y, Anderson CA, Essers J, Mitrovic M, Ning K, Cleynen I, Theatre E, Spain SL, Raychaudhuri S, Goyette P, Wei Z, Abraham C, Achkar JP, Ahmad T, Amininejad L, Ananthakrishnan AN, Andersen V, Andrews JM, Baidoo L, Balschun T, Bampton PA, Bitton A, et al: Host-microbe interactions have shaped the genetic architecture of inflammatory bowel disease. Nature 2012, 491:119-124.

6. Beaudoin M, Goyette P, Boucher G, Lo KS, Rivas MA, Stevens C, Alikashani A, Ladouceur M, Ellinghaus D, Torkvist L, Goel G, Lagacé C, Annese V, Bitton A, Begun J, Brant SR, Bresso F, Cho JH, Duerr RH, Halfvarson J, McGovern DP, Radford-Smith G, Schreiber S, Schumm PL, Sharma Y, Silverberg MS, Weersma RK, Quebec IBD Genetics Consortium; NIDDK IBD Genetics Consortium; International IBD Genetics Consortium, et al: Deep resequencing of GWAS loci identifies rare variants in CARD9, IL23R and RNF186 that are associated with Ulcerative colitis. Plos Genet 2013, 9:e1003723.

7. Anderson CA, Boucher G, Lees CW, Franke A, D'Amato M, Taylor KD, Lee JC, Goyette P, Imielinski M, Latiano A, Lagacé C, Scott R, Amininejad L, Bumpstead S, Baidoo L, Baldassano RN, Barclay M, Bayless TM, Brand S, Büning C, Colombel JF, Denson LA, De Vos M, Dubinsky M, Edwards C, Ellinghaus D, Fehrmann RS, Floyd JA, Florin T, Franchimont D, et al: Metaanalysis identifies 29 additional ulcerative colitis risk loci, increasing the number of confirmed associations to 47. Nat Genet 2011, 43:246-252.

8. Andoh A, Zhang Z, Inatomi O, Fujino S, Deguchi Y, Araki Y, Tsujikawa T, Kitoh K, Kim-Mitsuyama S, Takayanagi A, Shimizu N, Fujiyama Y: Interleukin22 , a member of the IL-10 subfamily, induces inflammatory responses in colonic subepithelial myofibroblasts. Gastroenterology 2005, 129:969-984.

9. Wolk K, Sabat R: Interleukin-22: a novel T- and NK-cell derived cytokine that regulates the biology of tissue cells. Cytokine Growth Factor Rev 2006, 17:367-380

10. Wolk K, Kunz S, Witte E, Friedrich M, Asadullah K, Sabat R: IL-22 increases the innate immunity of tissues. Immunity 2004, 21:241-254.

11. Boniface K, Bernard FX, Garcia M, Gurney AL, Lecron JC, Morel F: IL-22 inhibits epidermal differentiation and induces proinflammatory gene expression and migration of human keratinocytes. J Immunol 2005, 174:3695-3702.

12. Zenewicz LA, Yancopoulos GD, Valenzuela DM, Murphy AJ, Stevens S, Flavell RA: Innate and adaptive interleukin-22 protects mice from inflammatory bowel disease. Immunity 2008, 29:947-957.

13. Yu LZ, Wang HY, Yang SP, Yuan ZP, Xu FY, Sun C, Shi RH: Expression of interleukin-22/STAT3 signaling pathway in ulcerative colitis and related carcinogenesis. World J Gastroenterol 2013, 19:2638-2649.

14. Yamamoto-Furusho JK, Miranda-Perez E, Fonseca-Camarillo G, SanchezMunoz F, Dominguez-Lopez A, Barreto-Zuniga R: Colonic epithelial upregulation of interleukin 22 (IL-22) in patients with ulcerative colitis. Inflamm Bowel Dis 2010, 16:1823.

15. Hennig BJ, Frodsham AJ, Hellier S, Knapp S, Yee $\sqcup$, Wright M, Zhang L, Thomas HC, Thursz M, Hill AV: Influence of IL-10RA and IL-22 polymorphisms on outcome of hepatitis C virus infection. Liver Int 2007, 27:1134-1143

16. Endam LM, Bosse Y, Filali-Mouhim A, Cormier C, Boisvert P, Boulet LP, Hudson TJ, Desrosiers M: Polymorphisms in the interleukin-22 receptor alpha-1 gene are associated with severe chronic rhinosinusitis. Otolaryngol Head Neck Surg 2009, 140:741-747.

17. Weger W, Hofer A, Wolf P, El-Shabrawi Y, Renner W, Kerl H, Salmhofer W: Common polymorphisms in the interleukin-22 gene are not associated with chronic plaque psoriasis. Exp Dermatol 2009, 18:796-798.
18. Thompson CL, Plummer SJ, Tucker TC, Casey G, Li L: Interleukin-22 genetic polymorphisms and risk of colon cancer. Cancer Causes Control 2010, 21:1165-1170.

19. Ding GG, Zhang GL, Chen XC, Zhang MX, Yang L, Wang Z: A study on the relationship between single nucleotide polymorphisms of interleukin-22 and susceptibility to pulmonary tuberculosis. Zhonghua Jie He He Hu Xi Za Zhi 2012, 35:596-600.

20. Musolino C, Allegra A, Ferraro M, Aguennouz M, Russo S, Alonci A, Saitta S, Gangemi S: Involvement of T2677T multidrug resistance gene polymorphism in Interleukin 22 plasma concentration in B-chronic lymphocytic leukemia patients. Acta Oncol 2012, 51:406-408.

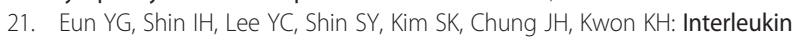
22 polymorphisms and papillary thyroid cancer. J Endocrinol Invest 2013, 36:584-587.

22. Suh JS, Cho SH, Chung JH, Moon A, Park YK, Cho BS: A polymorphism of interleukin-22 receptor alpha-1 is associated with the development of childhood IgA nephropathy. J Interferon Cytokine Res 2013, 33:571-577.

23. Podolsky DK: Inflammatory bowel disease. N Engl J Med 2002, 347:417-429.

24. Satsangi J, Silverberg MS, Vermeire S, Colombel JF: The Montreal classification of inflammatory bowel disease: controversies, consensus, and implications. Gut 2006, 55:749-753.

25. Truelove SC, Witts LJ: Cortisone in ulcerative colitis; final report on a therapeutic trial. Br Med J 1955, 2:1041-1048.

26. Langholz E, Munkholm P, Davidsen M, Binder V: Course of ulcerative colitis: analysis of changes in disease activity over years. Gastroenterology 1994, 107:3-11.

27. Sivaram G, Tiwari SK, Bardia A, Anjum F, Vishnupriya S, Habeeb A, Khan AA: Macrophage migration inhibitory factor, Toll-like receptor 4, and CD14 polymorphisms with altered expression levels in patients with ulcerative colitis. Hum Immunol 2012, 73:201-205.

28. Mo JS, Na KS, Yu Jl, Chae SC: Identification of the polymorphisms in IFITM1 gene and their association in a Korean population with ulcerative colitis. Immunol Lett 2013, 156:118-122.

29. Yamamoto-Furusho JK, De-Leon-Rendon JL, de la Torre MG, Alvarez-Leon E, Vargas-Alarcon G: Genetic polymorphisms of interleukin 20 (IL-20) in patients with ulcerative colitis. Immunol Lett 2013, 149:50-53.

30. Shiotani A, Kusunoki H, Kimura Y, Ishii M, Imamura H, Tarumi K, Manabe N, Kamada T, Hata J, Haruma K: S100A expression and interleukin-10 polymorphisms are associated with Ulcerative colitis and diarrhea predominant irritable bowel syndrome. Dig Dis Sci 2013, 58:2314-2323.

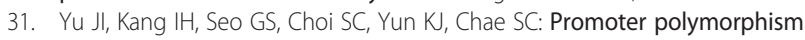
of the EED gene is associated with the susceptibility to Ulcerative colitis. Dig Dis Sci 2012, 57:1537-1543.

32. Zhang JX, He JH, Wang J, Song J, Lei HB, Wang J, Dong WG: Associations between PTPN2 polymorphisms and susceptibility to ulcerative colitis and Crohn's disease: a meta-analysis. Inflamm Res 2014, 63:71-79.

33. Xue LN, Xu KQ, Zhang W, Wang Q, Wu J, Wang XY: Associations between vitamin $D$ receptor polymorphisms and susceptibility to Ulcerative colitis and Crohn's disease: a meta-analysis. Inflamm Bowel Dis 2013, 19:54-60.

34. Wang B, Zhao XP, Fan YC, Zhang JJ, Zhao J, Wang K: IL-17A but not IL-22 suppresses the replication of hepatitis $B$ virus mediated by overexpression of MxA and OAS mRNA in the HepG2.2.15 cell line. Antiviral Res 2013, 97:285-292.

35. Moran CJ, Walters TD, Guo CH, Kugathasan S, Klein C, Turner D, Wolters VM, Bandsma RH, Mouzaki M, Zachos M, Langer JC, Cutz E, Benseler SM, Roifman CM, Silverberg MS, Griffiths AM, Snapper SB, Muise AM: IL-10R polymorphisms are associated with very-early-onset Ulcerative colitis. Inflamm Bowel Dis 2013, 19:115-123.

36. Bardia A, Tiwari SK, Gunisetty S, Anjum F, Nallari P, Habeeb MA, Khan AA: Functional polymorphisms in XRCC-1 and APE-1 contribute to increased apoptosis and risk of ulcerative colitis. Inflamm Res 2012, 61:359-365.

37. Yamamoto-Furusho JK, Santiago-Hernandez JJ, Perez-Hernandez N, RamirezFuentes S, Fragoso JM, Vargas-Alarcon G: Interleukin 1 beta (IL-1B) and IL-1 antagonist receptor (IL-1RN) gene polymorphisms are associated with the genetic susceptibility and steroid dependence in patients with Ulcerative colitis. J Clin Gastroenterol 2011, 45:531-535.

38. Yamamoto-Furusho JK, Alvarez-Leon E, Fragoso JM, Gozalishvilli A, Vallejo M, Vargas-Alarcon G: Protective role of interleukin-19 gene polymorphisms in patients with ulcerative colitis. Hum Immunol 2011, 72:1029-1032.

39. Wolk K, Warszawska K, Hoeflich C, Witte E, Schneider-Burrus S, Witte K, Kunz S, Buss A, Roewert HJ, Krause M, Lukowsky A, Volk HD, Sterry W, Sabat R: 
Deficiency of IL-22 contributes to a chronic inflammatory disease: pathogenetic mechanisms in acne inversa. J Immunol 2011, 186:1228-1239.

40. Zhang L, Cheng Z, Liu W, Wu K: Expression of interleukin (IL)-10, IL-17A and IL-22 in serum and sputum of stable chronic obstructive pulmonary disease patients. COPD 2013, 10:459-465.

41. Luo Z, Wang H, Sun Z, Luo W, Wu Y: Expression of IL-22, IL-22R and IL-23 in the peri-implant soft tissues of patients with peri-implantitis. Arch Oral Biol 2013, 58:523-529.

42. Cai T, Wang Q, Zhou Q, Wang C, Hou S, Qi J, Kijlstra A, Yang P: Increased expression of IL-22 is associated with disease activity in Behcet's disease. PLoS One 2013, 8:e59009.

43. Mathian A, Parizot C, Dorgham K, Trad S, Arnaud L, Larsen M, Miyara M, Hie M, Piette JC, Frances C, Yssel H, Amoura Z, Gorochov G: Activated and resting regulatory $T$ cell exhaustion concurs with high levels of interleukin-22 expression in systemic sclerosis lesions. Ann Rheum Dis 2012, 71:1227-1234.

44. Zhu J, Cao Y, Li K, Wang Z, Zuo P, Xiong W, Xu Y, Xiong S: Increased expression of aryl hydrocarbon receptor and interleukin 22 in patients with allergic asthma. Asian Pac J Allergy Immunol 2011, 29:266-272.

doi:10.1186/s13000-014-0183-y

Cite this article as: Chi et al: Association of the interleukin-22 genetic polymorphisms with ulcerative colitis. Diagnostic Pathology 2014 9:183.

\section{Submit your next manuscript to BioMed Central and take full advantage of:}

- Convenient online submission

- Thorough peer review

- No space constraints or color figure charges

- Immediate publication on acceptance

- Inclusion in PubMed, CAS, Scopus and Google Scholar

- Research which is freely available for redistribution 